\title{
ANALYSIS OF QUALITY INDICATOR ACHIEVEMENT ON LABORATORY SERVICE AT AL-MULK HOSPITAL, SUKABUMI, WEST JAVA
}

\author{
Lisna Agustiyah, Sudarto Ronoatmodjo \\ Masters Program in Public Health, Faculty of Public Health, Universitas Indonesia
}

\begin{abstract}
Background: The Ministry of Health has established 12 national quality indicators of compulsory hospital health services, one of which is time to report the results of laboratory critical test. The strategic objective of the laboratory critical value test report time implementation according to the standard is the realization of the hospital laboratory services organization based on quality and patient safety. Al-Mulk Regional Hospital has also established a hospital quality indicator in laboratory unit services, i.e. waiting times for laboratory services $<140$ minutes and no submission of incorrect laboratory results. It was in accordance with the Minimum Hospital Service Standards set out in the Ministry of Health Regulation Number 129/ 2008. This study aimed to analyze the quality indicator achievement of laboratory service at Al-Mulk hospital, Sukabumi.
\end{abstract}

Subjects and Method: This was a cross-sectional study conducted at the Laboratory unit of Al-Mulk Regional Hospital, Sukabumi, West Java, on August 2019. A total of 3 informants was selected for this study. The data were collected from the in-depth interview and the laboratory examination register book from May 2019 to July 2019.

Results: The average time to report a critical laboratory test was 23 minutes. The waiting time for laboratory services was 49 minutes. There were no errors in submitting laboratory results. The achievement of the quality of the report time the value of laboratory critical tests was $83 \%$. The achievement of the quality of waiting time for laboratory services was $92 \%$. The absence of wrong submission results has reached the set target of $100 \%$.

Conclusion: There are many factors that lead to an uncontrolled time of laboratory critical test reports causing the unreached of quality indicator achievement. The long waiting time for laboratory results is caused by the lack of employees, spatial planning, un-optimal room, and not well implemented of standard operating procedures.

Keywords: laboratory, quality

\section{Correspondence:}

Lisna Agustiyah. Masters Program in Public Health, Faculty of Public Health, Universitas Indonesia, Depok, West Java. Email: agustiyahlisna@gmail.com. Mobile: o81281183363. 